\title{
Devosia albogilva sp. nov. and Devosia crocina sp. nov., isolated from a hexachlorocyclohexane dump site
}

\author{
Mansi Verma, Mukesh Kumar, Mandeep Dadhwal, Jaspreet Kaur \\ and Rup Lal
}

Correspondence

Rup Lal

duzdel@vsnl.com
Molecular Biology Laboratory, Department of Zoology, University of Delhi, Delhi-110007, India

Two bacterial strains, IPL $15^{\top}$ and IPL $20^{\top}$, isolated from a hexachlorocyclohexane dump site in India, were characterized by using a polyphasic approach. Based on 16S rRNA gene sequence analysis, both strains belonged to the genus Devosia; highest sequence similarities of strain IPL $15^{\top}$ were observed with Devosia neptuniae $\mathrm{J} 1^{\top}$ and Devosia geojensis BD-c194 ${ }^{\top}$ (96.2\% in each case) and the highest sequence similarity of strain IPL $20^{\top}$ was observed with Devosia soli $\mathrm{GH} 2-10^{\top}(98.6 \%)$. Phylogenetic analysis showed the distinct lineages of strains $\mathrm{IPL}^{\mathrm{T}} 5^{\top}$ and IPL20 ${ }^{\top}$ among members of the genus Devosia. The presence of $\mathrm{C}_{18: 0} 3-\mathrm{OH}$ and $\mathrm{C}_{10: 0} 3-\mathrm{OH}$ fatty acids supported their respective positions within the genus Devosia. On the basis of phenotypic characteristics, phylogenetic analysis and DNA-DNA hybridization results, it is concluded that strains IPL $15^{\top}$ and IPL20 ${ }^{\top}$ represent two distinct species of the genus Devosia for which the names Devosia albogilva sp. nov. and Devosia crocina sp. nov., respectively, are proposed. The type strains are Devosia albogilva IPL $15^{\top}\left(=\mathrm{CCM} 7427^{\top}=\right.$ MTCC $\left.8594^{\top}\right)$ and Devosia crocina IPL20 ${ }^{\top}$ (= CCM $7425^{\top}=$ MTCC $\left.8590^{\top}\right)$.
The genus Devosia was first described by Nakagawa et al. (1996) with the transfer of Pseudomonas riboflavina (Foster, 1944) to Devosia riboflavina and currently comprises the following species: D. riboflavina (Nakagawa et al., 1996), D. neptuniae (Rivas et al., 2002, 2003), 'Candidatus Devosia euplotis' (Vannini et al., 2004), D. limi (Vanparys et al., 2005), D. soli (Yoo et al., 2006), D. insulae (Yoon et al., 2007), D. subaequoris (Lee, 2007), D. geojensis (Ryu et al., 2008) and D. chinhatensis (Kumar et al., 2008).

In our attempts to study the bacterial diversity of a hexachlorocyclohexane $(\mathrm{HCH})$-contaminated site in Chinhat, Lucknow, India, strains IPL15 ${ }^{\mathrm{T}}$ and $\mathrm{IPL} 20^{\mathrm{T}}$ were recovered on Luria-Bertani (LB) agar at $28{ }^{\circ} \mathrm{C}$ (Kumar et al., 2008). To check the HCH-degrading abilities of these isolates, each one of them was inoculated into $5 \mathrm{ml} \mathrm{LB}$ medium in $20 \mathrm{ml}$ test tubes supplemented with technical $\mathrm{HCH}\left(5 \mu \mathrm{g} \mathrm{ml}^{-1}\right)$ as described previously (Kumari et al.,

Abbreviations: $\mathrm{HCH}$, hexachlorocyclohexane; TEM, transmission electron microscope.

The GenBank/EMBL/DDBJ accession numbers for the 16S rRNA gene sequences of Devosia albogilva IPL $15^{\top}$ and Devosia crocina IPL20 ${ }^{\top}$ are EF433460 and EF433461, respectively.

Transmission electron micrographs of cells of the two novel strains, DNA-DNA hybridization data for strain $\mathrm{IPL}^{\top} \mathrm{O}^{\top}$ and related strains, and fatty acid profiles of the two novel strains and related species are available as supplementary material with the online version of this paper.
2002). Neither strain degraded the $\mathrm{HCH}$ isomers, in spite of their tolerance to very high levels of $\mathrm{HCH}$. These two strains were found to belong to the genus Devosia and have been characterized in the present study using a polyphasic taxonomic approach (Prakash et al., 2007b).

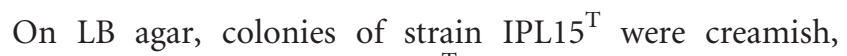
whereas those of strain IPL $20^{\mathrm{T}}$ were orange. Both strains formed circular colonies with entire margins and sizes varied from 0.5 to $2.0 \mathrm{~mm}$ when grown on LB agar at $28{ }^{\circ} \mathrm{C}$ for 3 days. Both strains were tested for their growth on tryptic soy agar (TSA) and nutrient agar (NA). Growth at different temperatures, $\mathrm{pH}$ and $\mathrm{NaCl}$ concentrations was determined as described by Arden Jones et al. (1979).

Gram stain was assessed using a HiMedia Gram Stain kit. The presence of flagella was detected using cells from the early exponential growth phase with a Philips CM-10 transmission electron microscope (TEM) at the All India Institute of Medical Sciences, New Delhi, India. Cells were negatively stained with $1 \%(\mathrm{w} / \mathrm{v})$ phosphotungstic acid and air-dried grids were examined by TEM. Each strain had a single polar flagellum (see Supplementary Fig. S1, available in IJSEM Online), in contrast to $D$. riboflavina DSM $7230^{\mathrm{T}}$, which possesses several polar flagella.

$16 \mathrm{~S}$ rRNA gene sequences of strains $\operatorname{IPL}^{2} 5^{\mathrm{T}}$ (1345 bp) and IPL20 $^{\mathrm{T}}$ (1361 bp) were determined as described previously (Kumar et al., 2008) and sequence analysis indicated that 
strains IPL15 $5^{\mathrm{T}}$ and IPL20 ${ }^{\mathrm{T}}$ belonged to the genus Devosia. Sequence alignment was done using the program CLUSTAL_X v.1.81b (Thompson et al., 1997). The evolutionary distance matrix was calculated using the distance model of Jukes and Cantor (1969) within the TREECONW software package v.1.3b (Van de Peer \& De Wachter, 1994) and the resultant tree topology was evaluated using bootstrap analysis of 1000 datasets. A phylogenetic tree was constructed using the neighbour-joining method of Saitou \& Nei (1987) and the resultant tree topology showed that strains IPL15 ${ }^{\mathrm{T}}$ and IPL20 ${ }^{\mathrm{T}}$ formed distinct phyletic lines among all previously reported Devosia species (Fig. 1). Similar tree topologies were obtained when phylogenetic trees were constructed by using the Kimura two-parameter matrix of the TREECONW software and the DNA parsimony method of the PHYLIP package v.3.5 (Felsenstein, 1993) (data not shown). Results confirmed that although strains IPL15 ${ }^{\mathrm{T}}$ and IPL2 $0^{\mathrm{T}}$ clustered in two different clades, they both belonged to the genus Devosia.

The 16S rRNA gene sequence similarity between strains IPL $15^{\mathrm{T}}$ and IPL $20^{\mathrm{T}}$ was only $96.1 \%$. 16S rRNA gene sequence similarities between strain $\mathrm{IPL}^{\mathrm{T}} 5^{\mathrm{T}}$ and the following strains are given in parentheses: $D$. neptuniae $\mathrm{J1}^{\mathrm{T}}(96.2 \%) ;$ D. geojensis BD-c194 ${ }^{\mathrm{T}}(96.2 \%)$; D. chinhatensis IPL18 ${ }^{\mathrm{T}}(96.0 \%)$; D. limi LMG $22951^{\mathrm{T}}$ (96.0\%); D. riboflavina DSM $7230^{\mathrm{T}}(95.9 \%)$; D. subaequoris HST3-14 ${ }^{\mathrm{T}}$ (95.9\%); D. insulae DS-56 ${ }^{\mathrm{T}}(95.5 \%)$; D. soli GH2 $-10^{\mathrm{T}}$ (95.2\%); 'Candidatus D. euplotis' CO (94.7\%); 'Candidatus D. euplotis' LIV5 (94.7\%); and 'Candidatus D. euplotis’ CAMP4.4 (94.6\%).

As low sequence similarities $(<97 \%)$ were found between strain IPL $15^{\mathrm{T}}$ and all species of the genus Devosia with validly published names (Stackebrandt \& Goebel, 1994), DNA-DNA hybridization studies of strain IPL $15^{\mathrm{T}}$ with its close relatives were not performed. On the other hand, strain IPL20 ${ }^{\mathrm{T}}$ showed highest $16 \mathrm{~S}$ rRNA gene sequence similarity of $98.6 \%$ with $D$. soli $\mathrm{GH} 2-10^{\mathrm{T}}$, followed by $D$. riboflavina DSM $7230^{\mathrm{T}}(97.8 \%)$, D. subaequoris HST3-14 ${ }^{\mathrm{T}}$ (96.8\%), D. limi LMG 22951 ${ }^{\mathrm{T}}(96.2 \%)$, D. neptuniae J1 ${ }^{\mathrm{T}}$ (95.9\%), 'Candidatus D. euplotis' CO (95.5\%), 'Candidatus D. euplotis' LIV5 (95.5\%), 'Candidatus D. euplotis' CAMP4.4 (95.4\%), D. geojensis BD-c194 ${ }^{\mathrm{T}}$ $(94.7 \%)$ and D. insulae DS- $56^{\mathrm{T}}(94.5 \%)$. Hence, DNADNA hybridization studies between strain IPL20 ${ }^{\mathrm{T}}, D$. soli $\mathrm{GH} 2-10^{\mathrm{T}}$ and D. riboflavina DSM $7230^{\mathrm{T}}$ were conducted by using the membrane filter method (Tourova \& Antonov, 1987). The experiment was performed as described by Bala et al. (2004). DNA-DNA relatedness values of strain IPL20 ${ }^{\mathrm{T}}$ with $D$. riboflavina DSM $7230^{\mathrm{T}}$ and D. soli GH2$10^{\mathrm{T}}$ were 12.1 and $9.8 \%$, respectively (see Supplementary

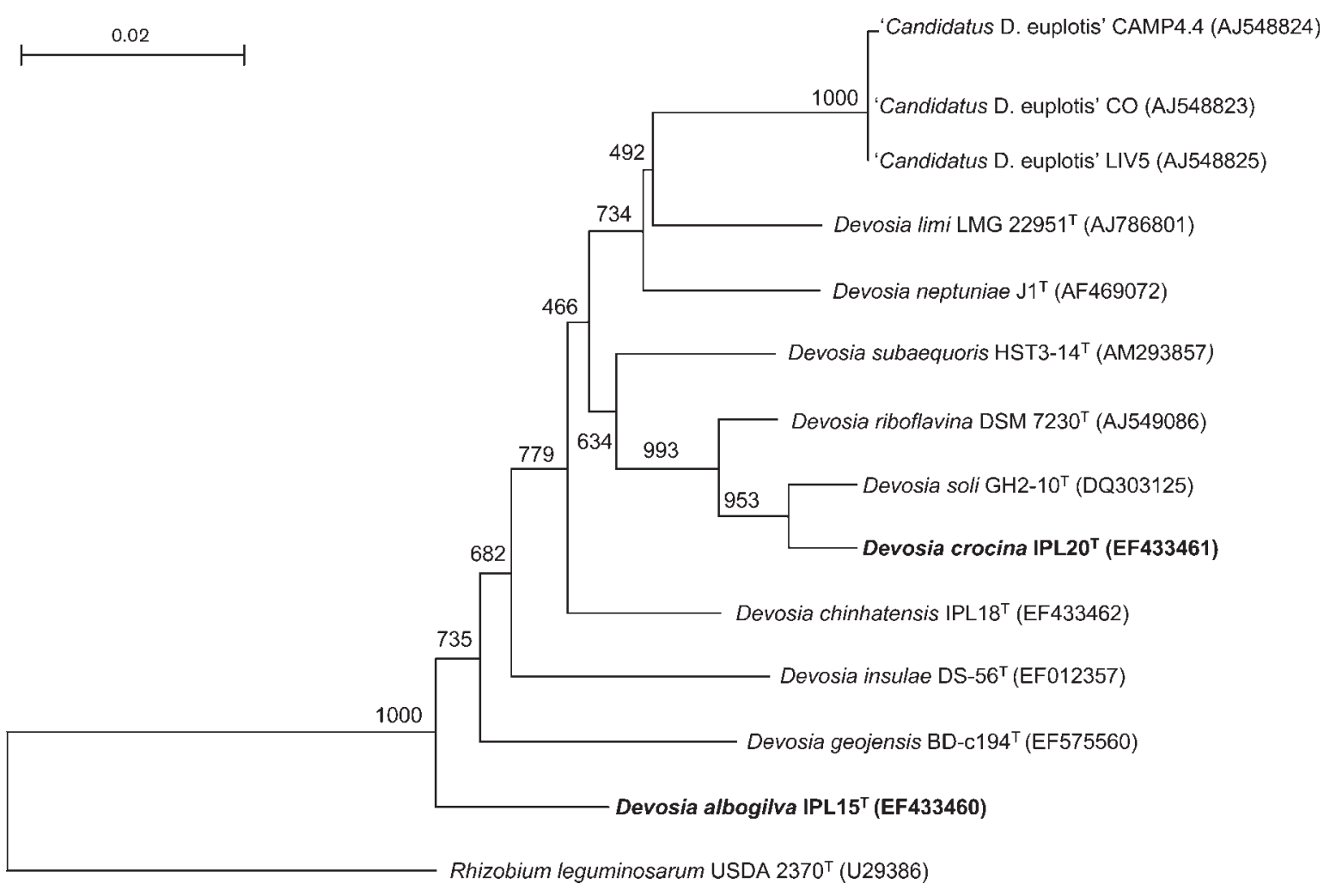

Fig. 1. Phylogenetic tree based on nearly complete 16S rRNA gene sequences (aligned positions) showing the relationship between strains IPL15 ${ }^{\top}$ and IPL20 ${ }^{\top}$ and related strains. Numbers at nodes represent bootstrap values (based on 1000 resamplings). GenBank accession numbers are shown in parentheses. Bar, 2 nt substitutions per $100 \mathrm{nt}$. 
Table S1, available in IJSEM Online). All the values were well below the threshold value of $70 \%$ that is recommended for delineation of genospecies (Stackebrandt \& Goebel, 1994), thus confirming that strain IPL20 ${ }^{\mathrm{T}}$ represents a novel species in the genus Devosia.

Fatty acid methyl ester analysis of strains $\operatorname{IPL}^{2} 5^{\mathrm{T}}$ and IPL $20^{\mathrm{T}}$ was carried out at $28{ }^{\circ} \mathrm{C}$ on TSA at IMTECH, Chandigarh, India, using the method of Miller (1982) and Kuykendall et al. (1988). The mixture of cellular fatty acids was separated using the Sherlock Microbial Identification system (Microbial ID) as described by Kumar et al. (2008). Fatty acid analysis indicated that strains IPL $15^{\mathrm{T}}$ and IPL $20^{\mathrm{T}}$ contained $\mathrm{C}_{18: 0} 3-\mathrm{OH}$ and $\mathrm{C}_{10: 0} 3-\mathrm{OH}$, features that are characteristic of members of the genus Devosia (see Supplementary Table S2, available in IJSEM Online). The predominant fatty acids of strain $\mathrm{IPL} 15^{\mathrm{T}}$ were iso- $\mathrm{C}_{15: 0}$ (23.2\%), summed feature $8\left(\mathrm{C}_{18: 1} \omega 7 c / \mathrm{C}_{18: 1} \omega 6 c ; 14 \%\right) 11$ methyl $\mathrm{C}_{18: 1} \omega 7 c(11.5 \%)$ and $\mathrm{C}_{16: 0}(9.9 \%)$. Interestingly, iso- $\mathrm{C}_{15: 0}$ has only been reported in trace amounts in $D$. insulae DS-56 ${ }^{\mathrm{T}}$ (Yoon et al., 2007). Other fatty acids of strain IPL15 ${ }^{\mathrm{T}}$ were unsaturated, branched and straightchain fatty acids that have not been observed in any Devosia species described so far: anteiso- $\mathrm{C}_{15: 0}(7.2 \%)$, iso$\mathrm{C}_{17: 1} \omega 10 c(4.9 \%), \mathrm{C}_{16: 1} \omega 11 c(3.5 \%)$, iso- $\mathrm{C}_{16: 0}(2.2 \%)$, $\mathrm{C}_{16: 1} \omega 7 c$ alcohol $(1.7 \%)$ and iso- $\mathrm{C}_{14: 0}(1.2 \%)$. On the other hand, summed feature $8 \quad\left(\mathrm{C}_{18: 1} \omega 7 c / \mathrm{C}_{18: 1} \omega 6 c\right.$; $60.7 \%), \mathrm{C}_{16: 0}(17.8 \%), \mathrm{C}_{18: 0}(6.7 \%)$ and 11-methyl $\mathrm{C}_{18: 1} \omega 7 c(5.0 \%)$ were the major fatty acids in strain IPL20 ${ }^{\mathrm{T}}$. A minor amount of anteiso- $\mathrm{C}_{17: 0}$ was also detected in strain IPL20 ${ }^{\mathrm{T}}$; this fatty acid has not been identified in other species of the genus Devosia described so far (see Supplementary Table S2, available in IJSEM Online). The fatty acid profile of strain IPL $20^{\mathrm{T}}$ differed not only from that of strain IPL $15^{\mathrm{T}}$, but also from that of its closest neighbour D. soli $\mathrm{GH} 2-10^{\mathrm{T}}$.

Results of chemotaxonomic analysis are given in the species description. Strains IPL $15^{\mathrm{T}}$ and IPL $20^{\mathrm{T}}$ were maintained on LB agar at $28{ }^{\circ} \mathrm{C}$ and all biochemical tests were conducted at $28{ }^{\circ} \mathrm{C}$ unless stated otherwise. The strains were tested for oxidase activity using Oxidase discs. Catalase activity was determined by bubble production in a $3 \%$ hydrogen peroxide solution (Merck) as described by McCarthy \& Cross (1984). Urease activity was tested using Christensen's method (Christensen, 1946). Assimilation of different carbohydrates was detected in basal media (Gordon et al., 1974). DNase activity was tested using HiMedia's DNase agar supplemented with $0.005 \%(\mathrm{w} / \mathrm{v})$ methyl green. Lipase production was assessed using $1 \%$ tributyrin and Tween 80. $\beta$-Galactosidase activity was observed using HiMedia ONPG discs. The presence of nitrate and nitrite was tested under anaerobic conditions after 24-48 h (Smibert \& Krieg, 1994; Prakash et al., 2007a). Production of indole was tested as described by Smibert \& Krieg (1994) and hydrolysis of casein, gelatin, starch and aesculin was determined as described by Cowan \& Steel (1965). Citrate utilization was tested on Simmons' citrate agar (Simmons, 1926). Susceptibility towards antibiotics was determined on LB agar using HiMedia readymade susceptibility test discs. Antibiotics tested were as follows (in $\mu \mathrm{g}$ unless stated otherwise): amikacin (30), ampicillin (10), chloramphenicol (30), ciprofloxacin (5), gentamicin (10), kanamycin (30), polymyxin B (300 U), rifamycin (5), tetracycline (30) and vancomycin (30).

Strain IPL $15^{\mathrm{T}}$ grew well on LB agar and NA, but slow growth was observed on TSA, whereas strain IPL20 ${ }^{\mathrm{T}}$ grew well on LB and TSA. Although all species of the genus Devosia reported so far are positive for catalase activity, strain IPL $20^{\mathrm{T}}$ was found to be catalase-negative. Strain IPL $15^{\mathrm{T}}$ could utilize glucose as sole carbon source, whereas strain IPL $20^{\mathrm{T}}$ could not. Unlike $D$. soli $\mathrm{GH} 2-10^{\mathrm{T}}$, strain IPL $20^{\mathrm{T}}$ was positive for assimilation of maltose, mannose, D-mannitol and L-arabinose (Table 1).

Based on the data presented above, it is apparent that strains IPL15 ${ }^{\mathrm{T}}$ and IPL20 ${ }^{\mathrm{T}}$ represent two novel species of the genus Devosia, for which the names Devosia albogilva sp. nov. and Devosia crocina sp. nov., respectively, are proposed.

\section{Description of Devosia albogilva sp. nov.}

Devosia albogilva (al.bo.gil'va. L. fem. adj. albogilva whitish yellow).

Cells are Gram-negative, aerobic, rod-shaped, non-sporeforming and motile with a single polar flagellum. Colonies are cream in colour and circular with entire margins (0.5$2.0 \mathrm{~mm}$ in size) when grown on LB agar plates for 3 days. Grows well on LB agar and NA, but less growth is seen on TSA. Temperature, $\mathrm{pH}$ and $\mathrm{NaCl}$ concentration ranges for growth are $5-45{ }^{\circ} \mathrm{C}, 5-9$ and $0-3 \%$, respectively. Assimilates L-arabinose, galactose, glucose, lactose, fructose, D-mannitol, mannose, xylose, maltose and sucrose, but not myo-inositol. Cells are positive for oxidase, catalase, urease and $\beta$-galactosidase activities and aesculin hydrolysis. Negative for DNase, lipase and nitrate reductase activities. Does not hydrolyse casein, gelatin or starch. Does not utilize citrate or produce indole. Sensitive to ciprofloxacin, gentamicin, chloramphenicol, rifampicin, amikacin, ampicillin, vancomycin and tetracycline; resistant to polymyxin B and kanamycin. Major cellular fatty acids are iso- $\mathrm{C}_{15: 0}$, summed feature 8 and 11-methyl $\mathrm{C}_{18: 1} \omega 7 c$.

The type strain is $\operatorname{IPL}^{2} 5^{\mathrm{T}}\left(=\mathrm{CCM} 7427^{\mathrm{T}}=\right.$ MTCC $\left.8594^{\mathrm{T}}\right)$, isolated from an $\mathrm{HCH}$ dump site in India.

\section{Description of Devosia crocina sp. nov.}

Devosia crocina (cro.ci'na. L. fem. adj. crocina saffroncoloured).

Gram-negative, aerobic, oval, non-spore-forming and motile with a single polar flagellum. Colonies are bright orange in colour, circular with entire margins and 0.5$2.0 \mathrm{~mm}$ in size when grown on LB agar plates for 3 days. Grows well on LB agar and TSA. Temperature, $\mathrm{pH}$ and $\mathrm{NaCl}$ concentration ranges for growth are $5-32{ }^{\circ} \mathrm{C}, 5-9$ and $0-3 \%$, respectively. Assimilates L-arabinose, galactose, 
Table 1. Differential phenotypic characteristics of strains $I P L 15^{\top}$ and IPL $20^{\top}$ and other Devosia species

Strains: 1, IPL15 ${ }^{\mathrm{T}}$ (Devosia albogilva sp. nov.); 2, IPL20 ${ }^{\mathrm{T}}$ (Devosia crocina sp. nov.); 3, D. riboflavina DSM 7230 ; 4, D. soli KACC $11509^{\mathrm{T}} ; 5$, D. neptuniae LMG 21357 ; 6, D. geojensis BD-c194 ${ }^{\mathrm{T}}$ (Ryu et al., 2008); 7, D. chinhatensis IPL18 ${ }^{\mathrm{T}}$; 8, D. limi LMG 22951 ${ }^{\mathrm{T}}$ (Vanparys et al., 2005; Yoo et al., 2006); 9, D. subaequoris HST3-14 ${ }^{\mathrm{T}}$ (Lee, 2007); 10, D. insulae DSM $17955^{\mathrm{T}}$ (Yoon et al., 2007). All strains are positive for $\beta$-galactosidase and aesculin hydrolysis. All are negative for gelatin hydrolysis, indole production, nitrate reduction, lipase, citrate production and susceptibility to polymyxin B. +, Positive; -, negative; $(+)$, weakly positive; ND, no data available.

\begin{tabular}{|c|c|c|c|c|c|c|c|c|c|c|}
\hline Characteristic & 1 & 2 & 3 & 4 & 5 & 6 & 7 & 8 & 9 & 10 \\
\hline Colony colour & Creamish & Orange & Cream & $\begin{array}{l}\text { Light } \\
\text { beige }\end{array}$ & $\begin{array}{l}\text { Pearl } \\
\text { white }\end{array}$ & White & Cream & $\begin{array}{c}\text { Light yellow } \\
\text { to light } \\
\text { brown }\end{array}$ & $\begin{array}{c}\text { Light yellow } \\
\text { to light } \\
\text { brown }\end{array}$ & Ivory \\
\hline Cell morphology & Ovals or rods & Oval & $\operatorname{Rods}^{*}$ & $\operatorname{Rods}^{*}$ & $\operatorname{Rods}^{*}$ & Rods & Rods & Rods & Rods & $\begin{array}{c}\text { Ovals or } \\
\text { rods }\end{array}$ \\
\hline Motility & + & + & $+^{*}$ & ND & $+^{*}$ & + & + & - & + & + \\
\hline Oxidase & + & + & + & - & + & + & + & + & + & - \\
\hline Urease & + & + & + & + & + & + & + & - & - & + \\
\hline Casein hydrolysis & - & - & - & - & + & + & - & - & - & - \\
\hline Starch hydrolysis & - & - & - & + & - & - & - & - & - & - \\
\hline Catalase & + & - & + & + & + & + & + & + & + & + \\
\hline \multicolumn{11}{|l|}{ Assimilation of: } \\
\hline Glucose & + & - & + & - & + & + & + & - & - & - \\
\hline L-Arabinose & + & + & + & - & + & - & + & - & - & - \\
\hline D-Mannitol & + & + & + & - & + & + & + & - & - & - \\
\hline Mannose & + & + & + & - & + & + & + & - & - & - \\
\hline Maltose & + & + & + & - & + & + & + & - & - & - \\
\hline Galactose & + & + & + & - & - & ND & + & ND & $\mathrm{ND}$ & $\mathrm{ND}$ \\
\hline Sucrose & + & - & - & - & - & $\mathrm{ND}$ & + & $\mathrm{ND}$ & $\mathrm{ND}$ & $\mathrm{ND}$ \\
\hline Lactose & + & + & + & - & + & $\mathrm{ND}$ & + & $\mathrm{ND}$ & $\mathrm{ND}$ & $\mathrm{ND}$ \\
\hline myo-Inositol & - & - & $(+)$ & - & - & ND & + & $\mathrm{ND}$ & $\mathrm{ND}$ & ND \\
\hline Xylose & + & + & + & - & $(+)$ & ND & + & $\mathrm{ND}$ & $\mathrm{ND}$ & $\mathrm{ND}$ \\
\hline \multicolumn{11}{|l|}{ Susceptibility to: $\dagger$} \\
\hline Gentamicin & S & S & $\mathrm{R}$ & $\mathrm{R}$ & $\mathrm{R}$ & $\mathrm{R}$ & S & $\mathrm{R}$ & $\mathrm{ND}$ & $\mathrm{R}$ \\
\hline Chloramphenicol & S & S & $\mathrm{R}$ & S & $\mathrm{R}$ & $\mathrm{R}$ & S & $\mathrm{R}$ & $\mathrm{ND}$ & S \\
\hline Kanamycin & $\mathrm{R}$ & $\mathrm{R}$ & $\mathrm{R}$ & S & $\mathrm{R}$ & $\mathrm{R}$ & $\mathrm{R}$ & $\mathrm{R}$ & ND & $\mathrm{R}$ \\
\hline Tetracycline & S & S & S & S & $\mathrm{R}$ & S & S & I & ND & S \\
\hline
\end{tabular}

${ }^{\star}$ Data from Yoo et al. $(2006)$.

$\dagger$ I, Intermediate; R, resistant; S, sensitive.

fructose, D-mannitol, mannose, xylose, maltose and lactose, but not sucrose, myo-inositol or glucose. Positive for oxidase, urease and $\beta$-galactosidase activities and aesculin hydrolysis, but negative for catalase, DNase, lipase and nitrate reductase activities. Does not hydrolyse casein, gelatin or starch. Does not utilize citrate or produce indole. Sensitive to ciprofloxacin, gentamicin, chloramphenicol, rifampicin, amikacin, ampicillin, vancomycin and tetracycline; resistant to polymyxin $\mathrm{B}$ and kanamycin. Major cellular fatty acids are $\mathrm{C}_{18: 1} \omega 7 c / \mathrm{C}_{18: 1} \omega 6 c$ and $\mathrm{C}_{16: 0}$.

The type strain is IPL20 ${ }^{\mathrm{T}}\left(=\mathrm{CCM} 7425^{\mathrm{T}}=\right.$ MTCC $\left.8590^{\mathrm{T}}\right)$, isolated from an $\mathrm{HCH}$ dump site in India.

\section{Acknowledgements}

This research was supported by funds from the Department of Biotechnology (DBT) and the National Bureau of Agriculturally Important Microorganisms (NBAIM), Government of India. M. V.,
M.K., M.D. and J.K. acknowledge the Council of Scientific and Industrial Research (CSIR), the Indian Council of Medical Research (ICMR) and the DBT for providing research fellowships. The authors thank J. P. Euzéby for etymological advice. The authors also thank Dr Encarna Velázquez, Universidad de Salamanca, Spain, and Dr SoonWo Kwon, Korean Agricultural Culture Collection (KACC), Korea, for providing Devosia riboflavina DSM $7230^{\mathrm{T}}$ and Devosia soli GH2$10^{\mathrm{T}}$, respectively.

\section{References}

Arden Jones, M. P., McCarthy, A. J. \& Cross, T. (1979). Taxonomic and serologic studies on Micropolyspora faeni and Micropolyspora strains from soil bearing the specific epithet rectivirgula. J Gen Microbiol 115, 343-344.

Bala, S., Khanna, R., Dadhwal, M., Prabhagaran, S. R., Shivaji, S., Cullum, J. \& Lal, R. (2004). Reclassification of Amycolatopsis mediterranei DSM 46095 as Amycolatopsis rifamycinica sp. nov. Int J Syst Evol Microbiol 54, 1145-1149. 
Christensen, W. B. (1946). Urea decomposition as a means of differentiating Proteus and paracolon cultures from each other and from Salmonella and Shigella types. J Bacteriol 52, 461-466.

Cowan, S. T. \& Steel, K. J. (1965). Manual for the Identification of Medical Bacteria. London: Cambridge University Press.

Felsenstein, J. (1993). PHYLIP (phylogeny inference package), version 3.5c. Distributed by the author. Department of Genome Sciences, University of Washington, Seattle, USA.

Foster, J. W. (1944). Microbiological aspects of riboflavin. I. Introduction. II. Bacterial oxidation of riboflavin to lumichrome. J Bacteriol 47, 27-41.

Gordon, R. E., Barnett, D. A., Handerhan, J. E. \& Pang, C. H.-N. (1974). Nocardia coeliaca, Nocardia autotrophica, and the nocardin strain. Int J Syst Bacteriol 24, 54-63.

Jukes, T. H. \& Cantor, C. R. (1969). Evolution of protein molecules. In Mammalian Protein Metabolism, vol. 3, pp. 21-132. Edited by H. N. Munro. New York: Academic Press.

Kumar, M., Verma, M. \& Lal, R. (2008). Devosia chinhatensis sp. nov., isolated from a hexachlorocyclohexane $(\mathrm{HCH})$ dump site in India. Int J Syst Evol Microbiol 58, 861-865.

Kumari, R., Subudhi, S., Suar, M., Dhingra, G., Raina, V., Dogra, C., Lal, S., van der Meer, J. R., Holliger, C. \& Lal, R. (2002). Cloning and characterization of lin genes responsible for the degradation of hexachlorocyclohexane isomers by Sphingomonas paucimobilis strain B90. Appl Environ Microbiol 68, 6021-6028.

Kuykendall, L. D., Roy, M. A., O’Neill, J. J. \& Devine, T. E. (1988). Fatty acids, antibiotic resistance, and deoxyribonucleic acid homology groups of Bradyrhizobium japonicum. Int J Syst Bacteriol 38, 358-361.

Lee, S. D. (2007). Devosia subaequoris sp. nov., isolated from beach sediment. Int J Syst Evol Microbiol 57, 2212-2215.

McCarthy, A. J. \& Cross, T. (1984). A taxonomic study of Thermomonospora and other monosporic actinomycetes. J Gen Microbiol 130, 5-25.

Miller, L. T. (1982). Single derivatization method for routine analysis of bacterial whole-cell fatty acid methyl esters, including hydroxy acids. J Clin Microbiol 16, 584-586.

Nakagawa, Y., Sakane, T. \& Yokota, A. (1996). Transfer of "Pseudomonas riboflavina" (Foster 1944), a gram-negative, motile rod with long-chain 3-hydroxy fatty acids, to Devosia riboflavina gen. nov., sp. nov., nom. rev. Int J Syst Bacteriol 46, 16-22.

Prakash, O., Kumari, K. \& Lal, R. (2007a). Pseudomonas delhiensis sp. nov., from a fly ash dumping site of a thermal power plant. Int J Syst Evol Microbiol 57, 527-531.

Prakash, O., Verma, M., Sharma, P., Kumar, M., Kumari, K., Singh, A., Kumari, H., Jit, S., Gupta, S. K. \& other authors (2007b). Polyphasic approach of bacterial classification - an overview of recent advances. Indian J Microbiol 47, 98-108.

Rivas, R., Velázquez, E., Willems, A., Vizcaíno, N., Subba-Rao, N. S., Mateos, P. F., Gillis, M., Dazzo, F. B. \& Martínez-Molina, E. (2002). A new species of Devosia that forms a unique nitrogen-fixing rootnodule symbiosis with the aquatic legume Neptunia natans (L.f.) Druce. Appl Environ Microbiol 68, 5217-5222.

Rivas, R., Willems, A., Subba-Rao, N. S., Mateos, P. F., Dazzo, F. B., Kroppenstedt, R. M., Martínez-Molina, E., Gillis, M. \& Velázquez, E. (2003). Description of Devosia neptuniae sp. nov. that nodulates and fixes nitrogen in symbiosis with Neptunia natans, an aquatic legume from India. Syst Appl Microbiol 26, 47-53.

Ryu, S. H., Chung, B. S., Le, N. T., Jang, H. H., Yun, P.-Y., Park, W. \& Jeon, C. O. (2008). Devosia geojensis sp. nov., isolated from dieselcontaminated soil in Korea. Int J Syst Evol Microbiol 58, 633-636.

Saitou, N. \& Nei, M. (1987). The neighbor-joining method: a new method for reconstructing phylogenetic trees. Mol Biol Evol 4, 406-425.

Simmons, J. S. (1926). A culture medium for differentiating organisms of typhoid-colon-aerogenes groups and for the isolation of certain fungi. J Infect Dis 39, 209-214.

Smibert, R. M. \& Krieg, N. R. (1994). Phenotypic characterization. In Methods for General and Molecular Bacteriology, pp. 607-654. Edited by P. Gerhardt, R. G. E. Murray, W. A. Wood \& N. R. Krieg. Washington, DC: American Society for Microbiology.

Stackebrandt, E. \& Goebel, B. M. (1994). Taxonomic note: a place for DNA-DNA reassociation and 16S rRNA sequence analysis in the present species definition in bacteriology. Int J Syst Bacteriol 44, 846849.

Thompson, J. D., Gibson, T. J., Plewniak, F., Jeanmougin, F. \& Higgins, D. G. (1997). The CLUSTAL_X windows interface: flexible strategies for multiple sequence alignment aided by quality analysis tools. Nucleic Acids Res 25, 4876-4882.

Tourova, T. P. \& Antonov, A. S. (1987). Identification of microorganisms by rapid DNA-DNA hybridization. Methods Microbiol 19, 333355.

Van de Peer, Y. \& De Wachter, Y. (1994). TREECON for Windows: a software package for the construction and drawing of evolutionary trees for the Microsoft Windows environment. Comput Appl Biosci 10, 569-570.

Vannini, C., Rosati, G., Verni, F. \& Petroni, G. (2004). Identification of the bacterial endosymbionts of the marine ciliate Euplotes magnicirratus (Ciliophora, Hypotrichia) and proposal of 'Candidatus Devosia euplotis'. Int J Syst Evol Microbiol 54, 1151-1156.

Vanparys, B., Heylen, K., Lebbe, L. \& De Vos, P. (2005). Devosia limi sp. nov., isolated from a nitrifying inoculum. Int J Syst Evol Microbiol 55, 1997-2000.

Yoo, S. H., Weon, H. Y., Kim, B. Y., Hong, S. B., Kwon, S. W., Cho, Y. H., Go, S. J. \& Stackebrandt, E. (2006). Devosia soli sp. nov., isolated from greenhouse soil in Korea. Int J Syst Evol Microbiol 56, 2689-2692.

Yoon, J.-H., Kang, S.-J., Park, S. \& Oh, T.-K. (2007). Devosia insulae sp. nov., isolated from soil, and emended description of the genus Devosia. Int J Syst Evol Microbiol 57, 1310-1314. 